\title{
A new promoterless reporter vector reveals antisense transcription in Mycoplasma genitalium
}

Correspondence

Jaume Piñol

jaume.pinyol@uab.es

Received 27 October 2006

Revised 16 April 2007

Accepted 23 April 2007

\author{
Maria Lluch-Senar, Miquel Vallmitjana, Enrique Querol and Jaume Piñol
}

Institut de Biotecnologia i Biomedicina and Departament de Bioquímica i Biologia Molecular, Universitat Autònoma de Barcelona, 08193 Bellaterra, Barcelona, Spain

\begin{abstract}
The mechanisms that promote and regulate transcription in mycoplasmas are poorly understood. Here, a promoter-probe vector based on the pMTnTetM438 minitransposon and containing a promoterless lacZ reporter gene was constructed to analyse Mycoplasma genitalium transcription in vivo. Recovered transposon insertions were in monocopy, with $16 \%$ expressing enough $\beta$-galactosidase ( $\beta$-Gal) to yield colonies exhibiting a detectable blue colour. A sample of 52 blue colonies was propagated and selected for further analyses. The $\beta$-Gal activity of the corresponding cultures was measured to quantify, in a reproducible way, the transcription levels of the interrupted ORFs. Several insertions were found in sense with the interrupted ORF, but surprisingly there was also a number of insertions in non-coding regions, many of them in repetitive DNA regions known as $\mathrm{MgPa}$ islands. Moreover, $30 \%$ of the analysed transposon insertions had the lac $Z$ gene in the opposite orientation to the coding frame, suggesting the existence of antisense transcripts that may be involved in the control of gene expression in M. genitalium.
\end{abstract}

\section{INTRODUCTION}

Mycoplasmas are considered the smallest and simplest freeliving micro-organisms. With small circular genomes, they are members of the class Mollicutes, which is characterized by the complete absence of cell wall and a low $\mathrm{G}+\mathrm{C}$ content. Many mycoplasmas are primarily mucosal pathogens and some of them are agents of common human diseases. Their parasitic lifestyle has enabled mycoplasmas to dispense with genes for numerous biosynthetic pathways. Genome sequencing has advanced the knowledge concerning the genetics and physiology of these organisms, but several aspects, especially at the transcriptional level, remain obscure. Analysis of the genome sequences reveals the presence of a single sigma factor and the absence of a transcription-termination Rho factor. Most Mycoplasma pneumoniae ORFs apparently lack typical signals such as the -35 box and the ribosome-binding site (RBS) found, respectively, in bacterial promoters and transcript leaders (Osada et al., 1999; Weiner et al., 2000). These data together with the current dearth of identified regulatory genes have compelled some investigators to suggest the presence in these organisms of novel and still unknown mechanisms to regulate gene expression, at both the transcriptional and the translational level.

\footnotetext{
Abbreviations: 6-Fam, 6-carboxifluorescein phosphoramidite; $\beta$-Gal, $\beta$ galactosidase.

Two supplementary figures and a supplementary table are available with the online version of this paper.
}

Mycoplasma genitalium is a human pathogen causing Chlamydia-negative non-gonococcal urethritis and it is phylogenetically related to $M$. pneumoniae, the causative agent of walking pneumonia and other extra-pulmonary pathologies in humans (Chiner et al., 2003; Jensen, 2004). With only 525 ORFs, M. genitalium has the smallest genome of any organism that can be grown in pure or axenic culture, which makes it an appealing model of a minimal cell. The genome of this micro-organism also shows several regions of repetitive DNA (the $\mathrm{MgPa}$ islands) that contain sequences derived from the ORFs related to cytadherence in the MgPa operon (Peterson et al., 1995). Studies concerning transcriptional analysis of $M$. genitalium ORFs are very scarce and limited to a few ORFs. These works have relied on the use of real-time RT-PCR (Benders et al., 2005) and macroarrays (Musatovova et al., 2006a). In addition, microarrays have been used in the related species M. pneumoniae and M. hyopneumoniae (Madsen et al., 2006a, b; Weiner et al., 2003). Therefore, the availability of promoter-probe vectors could benefit the study of gene expression and regulation in these micro-organisms, since this technique makes possible the detection of transcripts which are not usually considered when using other strategies. Moreover, a promoterless vector based on the lac $Z$ gene is a simple and well-known system for studying gene expression.

Several mycoplasma promoter-probe vectors based on the Tn4001 transposon have been developed (Dybvig et al., 2000; Knudtson \& Minion, 1993). Although a reporter vector has been recently described in $M$. pneumoniae (Halbedel \& Stulke, 2006), no specialized promoter-probe 
vectors are currently available in $M$. genitalium. We have previously developed the pMTnTetM438 minitransposon vector, which significantly improves transformation efficiency in M. genitalium (Pich et al., 2006b) and has been used to isolate mutants with transposon insertions in ORFs related to gliding motility (Pich et al., 2006a). In the present work, we report the construction of a promoterprobe vector based on the pMTnTetM438 plasmid and the results of a first survey aimed to study in vivo the transcription in M. genitalium. Many transposon insertions were located in ORFs expected to be highly transcribed (i.e. $\mathrm{MgPB}, \mathrm{P} 140$ adhesin gene). However, we have also detected a considerable amount of transposon insertions in intergenic regions and in the non-coding strand of many ORFs. In the absence of identified regulatory genes, the presence of antisense transcripts may provide the first mechanism to regulate gene expression in M. genitalium.

\section{METHODS}

Bacterial strains and growth conditions. Escherichia coli strain $\mathrm{XL}-1$ Blue was grown at $37{ }^{\circ} \mathrm{C}$ in $2 \mathrm{YT}$ broth or LB agar plates containing $75 \mu \mathrm{g}$ ampicillin $\mathrm{ml}^{-1}, 40 \mu \mathrm{g} \mathrm{X}-\mathrm{Gal} \mathrm{ml}^{-1}$ and $24 \mu \mathrm{g}$ IPTG $\mathrm{ml}^{-1}$ when needed. M. genitalium G-37 (wild-type) strain was grown in SP-4 medium (Tully et al., 1979) at $37{ }^{\circ} \mathrm{C}$ under $5 \% \mathrm{CO}_{2}$ in tissue culture flasks (TPP). To select mycoplasma colonies expressing the lac $Z$ gene, plates were supplemented with $2 \mu \mathrm{g}$ tetracycline $\mathrm{ml}^{-1}$ and $150 \mu \mathrm{g} \mathrm{X}-\mathrm{Gal} \mathrm{ml} \mathrm{m}^{-1}$.

DNA manipulations. All primers used in this work are listed in Table 1. Plasmid DNA was obtained by using the Fast Plasmid Mini Eppendorf kit. The purification of PCR products and digested fragments from agarose gels was achieved using the E.Z.N.A. Gel Extraction kit (Omega BIO-TEK). The E. coli lacZ gene from plasmid pMC1871 (Shapira et al., 1983) was amplified by PCR using the primers lac5b and lac3 or alternatively lac5a and lac3 (Table 1). The first set of primers adds the RBS sequence from the Bacillus subtilis cit $Z$ gene and a translation start codon in-frame with the $5^{\prime}$ end of the lac $Z$ gene. The second set adds only the translation start codon to the lac $Z$ coding sequence. Both PCR products were inserted into the pMTnTetM438 minitransposon (Pich et al., 2006b) between the XhoI and SalI sites to obtain the placRBS ${ }^{+}$and placRBS ${ }^{-}$constructs.

Transformation of $\boldsymbol{M}$. genitalium. Transformation of M. genitalium was performed as previously described (Pich et al., 2006b; Reddy et al., 1996) with some modifications. Briefly, a mid-exponential-phase $M$. genitalium culture grown in SP-4 medium in $150 \mathrm{~cm}^{2}$ tissue culture flasks was washed three times with electroporation buffer $(8 \mathrm{mM}$ HEPES, pH 7.2, $272 \mathrm{mM}$ sucrose). Cells were scraped off and resuspended in electroporation buffer at a concentration of approximately $10^{9}$ cells $\mathrm{ml}^{-1}$. Then, $90 \mu \mathrm{l}$ aliquots were placed in $2 \mathrm{~mm}$ gapped electroporation cuvettes and mixed with $10 \mu \mathrm{g}$ plasmid DNA dissolved in electroporation buffer. After $15 \mathrm{~min}$ in ice, cells were electroporated at $2.5 \mathrm{kV}, 50 \mu \mathrm{F}$ and $129 \Omega$ in an electrocell manipulator 600 (BTX) and immediately kept in ice for another $15 \mathrm{~min}$. Then $900 \mu$ l SP-4 medium was added and the cells were incubated for $2 \mathrm{~h}$ at $37^{\circ} \mathrm{C}$. Aliquots of $200 \mu \mathrm{l}$ were spread on SP-4 agar plates supplemented with $2 \mu \mathrm{g}$ tetracycline $\mathrm{ml}^{-1}$ and $150 \mu \mathrm{g} \mathrm{X}-\mathrm{Gal} \mathrm{ml} \mathrm{ml}^{-1}$ and incubated at $37{ }^{\circ} \mathrm{C}$ in $5 \% \mathrm{CO}_{2}$. Only well-isolated blue colonies were picked, propagated in 96-well plates containing $200 \mu \mathrm{l} \mathrm{SP}-4$ medium and stored at $-80{ }^{\circ} \mathrm{C}$ until analysed.

Genomic DNA manipulations. After growing transformants in $75 \mathrm{~cm}^{2}$ cell culture flasks with $20 \mathrm{ml} \mathrm{SP}-4$ medium, cells were scraped
Table 1. Primers used in this study

\begin{tabular}{|c|c|}
\hline Name $^{*}$ & Sequence $\left(5^{\prime}-3^{\prime}\right)$ \\
\hline lac5b & $\begin{array}{l}\text { CTCGAGAAAGGAGATGTTATATATGGATCC- } \\
\text { CGTCGTTTTACAACGTC }\end{array}$ \\
\hline lac3 & ACGAGCGTGACACCAAGATG \\
\hline lac5a & CTCGAGATGGATCCCGTCGTTTTACAACGTC \\
\hline Ntergal & CAAGGCGATTAAGTTGGGTAACG \\
\hline mg354Fam & ATCTCTTCCAATAATAGGATCGACC \\
\hline MgPaVIFam & ACСССТСТТССТАТСAAATCGCTG \\
\hline Amg298 & AAATTGATGAAATTGCTAGCAATGAG \\
\hline Smg298 & CTGCAAAGGTTTTAGTTAC \\
\hline AMgPaIV & CAAAAGTTACCTCAACACCAAG \\
\hline SMgPaIV & GGTTTTAAAAACССТTTCATCTC \\
\hline Amg191 & CAATGGCCAGGGAGCAAC \\
\hline Smg191 & CTGCTTGTAATGCCTTTTTG \\
\hline Amg226 & ATGACCATGTTTGATGTTGG \\
\hline Smg226 & АСААСАААААСССАССТАСТ \\
\hline Amg227 & GAAAACTTTAAAAAATCACCAAG \\
\hline Smg227 & TTAACTTAGTTTCATGAGCAAC \\
\hline Amg269 & CTACGAACAAGCAACCCAAA \\
\hline Smg269 & ATTGGCTTCTTTTATTGCATGT \\
\hline Amg288 & TGAAAAAGCTAAAGCTGATTA \\
\hline Smg288 & СTTTTTCACTAAAGGCTTTCT \\
\hline Amg294 & TAATTGCATTGATAATTACCAGCA \\
\hline Smg294 & ATAGCTTTTACACTTATCT \\
\hline Amg525 & TTAACTAGCCTTGTTTATGATAT \\
\hline Smg525 & GTAAATAAAAACAGTGATAAACAAA \\
\hline Amg414 & AGCGTTGAATTGCTAAAGATT \\
\hline Smg414 & ATCTAATTCAGCAATTTTTAAGT \\
\hline Amg354 & GATTTTATCTGTTCTACAAGAGA \\
\hline Smg354 & TTTTGATCAACAGTTTGGTGCA \\
\hline Amg359 & TTGAACCTTTTTTGTTGCGTG \\
\hline Smg359 & AAAGGGATAGTTGTGCAATTG \\
\hline Amg200 & TGAATATGAACTGTTGCAAGAC \\
\hline Smg200 & CTAACAGTTCCTTTTCAATCA \\
\hline Amg224 & GTACAGGTGCTACCCCAG \\
\hline Smg224 & ATCTGCTTGAAGTTAAGCTTG \\
\hline Amg131 & TTATTTTTTGCTTATTGCATCGA \\
\hline Smg131 & GGTTTGTGGCAAATTCCTTTTCTTTTTGA \\
\hline
\end{tabular}

*Primer names beginning with 'A' or ' $S$ ' were used in the RT-PCR reactions.

off and genomic DNA was isolated by using the E.Z.N.A. Bacterial DNA kit (Omega BIO-TEK). Southern blot hybridizations were performed by using the $1.13 \mathrm{~kb}$ XhoI-EcoRV fragment of the pLacRBS $^{+}$plasmid as a probe and the DNA Dig labelling and detection kit (Roche). Sequencing reactions were performed with fluorescent dideoxynucleotides using the primer Ntergal and the BigDye Terminator v3.0 Cycle Sequencing kit (Applied Biosystems) following the recommendations of the manufacturer. Sequence reactions were analysed in an ABI 3100 Genetic Analyzer (Applied Biosystems). The sequences obtained were aligned with the current release of the $M$. genitalium G-37 genome (version L43967.2, GI:84626123) using the BLAST program (Altschul et al., 1997) to determine the precise insertion sites. The codon usage bias of the highly expressed genes was analysed using the GCUA-WIN program (McInerney, 1998). The transcription terminators in $M$. genitalium were predicted using the Transterm program (http://nbcl1.biologie.uni-kl.de/framed/left/ 
menu/auto/right/transterm/) (Ermolaeva et al., 2000) and those showing a confidence equal or better than $98 \%$ were selected.

Measurement of $\boldsymbol{\beta}$-galactosidase ( $\boldsymbol{\beta}$-Gal) activity. Cultures were grown in suspension in $10 \mathrm{ml} \mathrm{SP}-4$ medium to mid-exponential phase as determined by medium colour change. Then, $1.5 \mathrm{ml}$ of culture was centrifuged for $15 \mathrm{~min}$ at $14000 \mathrm{~g}$ and the cells were resuspended in $75 \mu \mathrm{l}$ lysis solution. A volume of $10 \mu \mathrm{l}$ was processed using the ATP Bioluminescence Assay kit HS II (Roche) to determine the ATP content. Measuring ATP instead of turbidity is considered the best method to estimate the mycoplasma cell mass (Robertson \& Stemke, 1995). The remainder of the cell lysate was used to determine the $\beta$-Gal activity by a modified Miller test (Miller \& Hershberger, 1984). Briefly, $65 \mu \mathrm{l}$ cell lysate was mixed with $585 \mu \mathrm{l}$ buffer $\mathrm{Z}$ (0.06 $\mathrm{M} \mathrm{Na}_{2} \mathrm{HPO}_{4}, 0.04 \mathrm{M} \mathrm{NaH}_{2} \mathrm{PO}_{4}, 0.02 \mathrm{M} \mathrm{KCl}, 1 \mathrm{mM} \mathrm{MgSO}$, $0.28 \% \beta$-mercaptoethanol) and $65 \mu \mathrm{l}$ chloroform, vortexed vigorously and kept in a bath at $28{ }^{\circ} \mathrm{C}$ for $5 \mathrm{~min}$. Then $130 \mu \mathrm{l} \mathrm{ONPG}$ was added to the sample. When the sample became yellow, the reaction was stopped by addition of $325 \mu \mathrm{l} 0.5 \mathrm{M} \mathrm{Na}_{2} \mathrm{CO}_{3}$. The time between substrate addition and colour change was measured. Finally, the samples were centrifuged $15 \mathrm{~min}$ at $14000 \mathrm{~g}$ and the supernatant absorbance was recorded at $420 \mathrm{~nm}$.

RNA manipulations and primer extension assay. Total RNA was isolated using the TRI Reagent kit (Invitrogen) following the recommendations of the manufacturer. Before the RT-PCR assays, total RNA was treated with DNase I (New England Biolabs). Retrotranscription reactions in primer extension assays and RT-PCR reactions were performed using a strand-specific primer and the SuperScript First-Strand Synthesis kit (Invitrogen) according to the instructions of the manufacturer. The RT-PCR negative controls were performed using non-reverse-transcribed RNA as a template. In primer extension assays, the retrotranscription reactions were carried out using 10-20 $\mu \mathrm{g}$ total RNA and 2 pmol of a 6-carboxifluorescein phosphoramidite (6-Fam)-labelled primer (Lloyd et al., 2005). The 6-Fam-labelled cDNA was treated with 2 units RNase $\mathrm{H}$ for $20 \mathrm{~min}$ at $37{ }^{\circ} \mathrm{C}$ and precipitated with ethanol. The sample was then redissolved in $10 \mu \mathrm{l}$ formamide and mixed with $0.5 \mu \mathrm{l}$ ROX markers (Applied Biosystems). Electrophoresis was performed using an ABI $3130 \mathrm{XL}$ Genetic Analyzer (Applied Biosystems) and the DNA fragments were sized using the GENESCAN analysis software (Applied Biosystems).

\section{RESULTS}

\section{Construction of pLacRBS ${ }^{+}$and $\mathrm{pLacRBS}^{-}$vectors}

We have used lacZ as a reporter gene to analyse the transcription in M. genitalium. For this purpose, two constructs named pLacRBS $^{+}$and pLacRBS $^{-}$were designed. Both plasmids contain the lac $Z$ gene between the inverted repeats of the MTnTetM438 minitransposon with and without the RBS of the B. subtilis citZ gene (Fig. 1a) as well as the TetM438 marker, which effectively confers tetracycline resistance to the M. genitalium transformant cells.

A total of approximately 6000 colonies from four separate experiments were visible 10 days after transformation with the pLacRBS $^{+}$and pLacRBS $^{-}$plasmids. Blue colour was detected in only $16 \%$ of colonies derived from placRBS ${ }^{+}$ transformant cells after an additional incubation period of 1-2 weeks at $37^{\circ} \mathrm{C}$. No blue colour was detected in the pLacRBS $^{-}$transformant cells, even after extended incubation periods of 1 month at $37{ }^{\circ} \mathrm{C}$, highlighting the need for a)

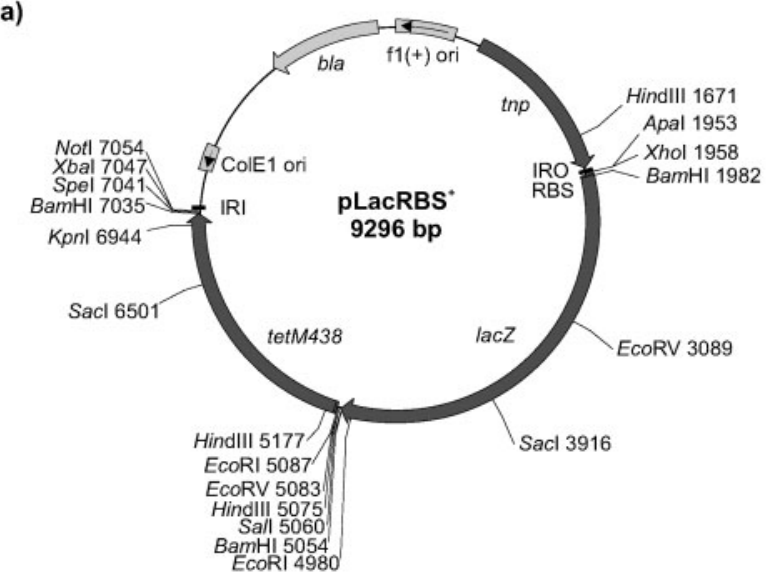

b)

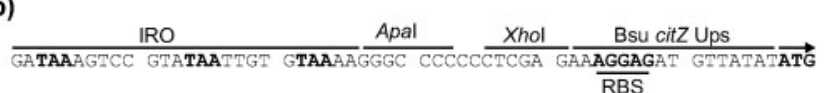

c)

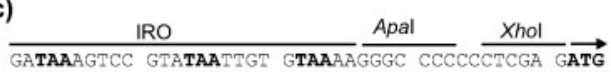

Fig. 1. Construction of pLacRBS ${ }^{+}$. (a) Schematic representation of the pLacRBS $^{+}$vector. In this construct, the lac $Z$ gene containing an RBS from the $B$. subtilis (Bsu) citZ gene is inserted between the two inverted repeats (IRO, IRI) of the pMTnTetM438 minitransposon (Pich et al., 2006b). bla, $\beta$-lactamase; f1(+) ori, single-stranded replication origin; ColE1 ori, vegetative replication origin; tnp, transposase from Tn4001. (b, c) Sequences upstream of lac $Z$ in pLacRBS ${ }^{+}$and pLacRBS ${ }^{-}$, respectively. The three stop codons in each of the three possible reading frames and the RBS sequence are indicated in bold.

an RBS signal to promote the translation of the lac $Z$ gene in polycistronic transcripts. Blue colonies exhibited different colour shades, from pale to dark blue and, in many cases, this colour was more intense in the centre of the colony (Fig. 2c), as previously reported for colonies of $M$. gallisepticum and M. pneumoniae transformed with lacZ promoter-probe vectors (Halbedel \& Stulke, 2006; Knudtson \& Minion, 1993).

\section{Analyses of transposon insertion sites}

DNAs from 52 independent clones derived from blue colonies were analysed by Southern blotting. A single band was detected in 49 out of 52 clones (data not shown), suggesting that the corresponding cultures were pure and stable. Transposon insertion sites were determined by sequencing genomic DNA from pure cultures (Table 2). The Southern blot data were also consistent with the transposon insertion sites derived from sequencing analysis (Table 2).

Although most of the transposon insertions were found inside coding regions, only 20 of them were expected to disrupt the respective coding region as they fell within the $5^{\prime}$-most $80 \%$ of the ORF and were located after at least 
a)

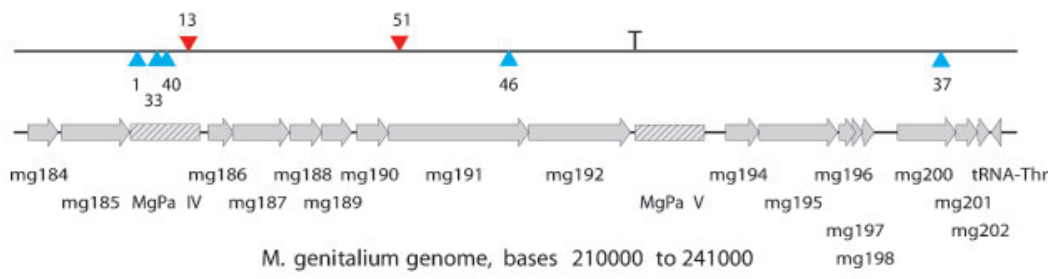

b)

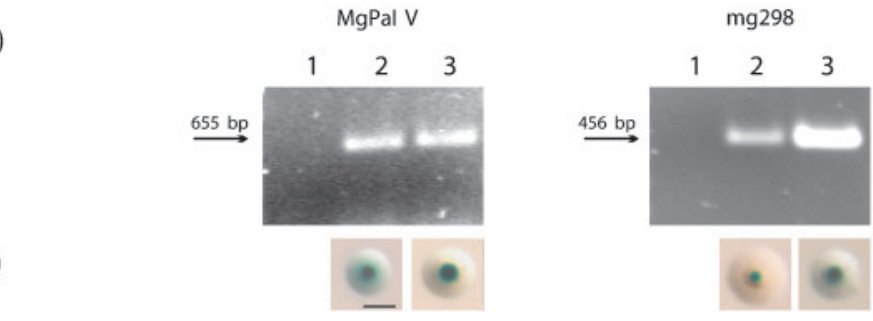

d)

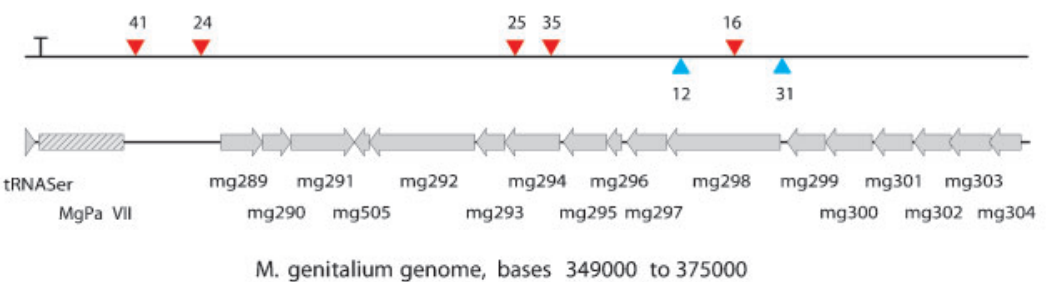

Fig. 2. Detection by RT-PCR of transcripts from $\mathrm{MgPa}$ island IV and the $\mathrm{mg} 298 \mathrm{ORF}$ of $M$. genitalium G-37. (a, d) Schematic representations of minitransposon insertion sites in the regions containing the $\mathrm{MgPa}$ island IV and the mg298 ORF, respectively. The red downwardfacing triangles in the upper line indicate transposon insertion sites in the plus strand; the blue upward-facing triangles indicate transposon insertion sites in the minus strand. The transcription terminator sequences were determined by the TransTerm program (Ermolaeva et al., 2000) and are marked with a T. (b) RT-PCR reactions from MgPa island IV and $m g 298$ ORF. Total RNA from M. genitalium G-37 was retrotranscribed using strandspecific primers, and PCR amplifications were analysed by gel electrophoresis. Lanes: 1, negative control; 2, RT-PCR reactions for the plus strand transcripts; $3, \mathrm{RT}-\mathrm{PCR}$ reaction for the minus strand transcripts. (c) lac $Z$ expression in colonies derived from pLacRBS $^{+}$ transformants. Left to right, micrographs of representative colonies from clones $40,13,12$ and 16 , containing the respective transposon insertions in the region analysed by RT-PCR. All micrographs are at the same magnification (bar, $0.25 \mathrm{~mm}$ ). three codons from the start of the protein-coding region (Glass et al., 2006; Supplementary Table S1, available with the online version of this paper). Two potentially disruptive insertions were identified in ORFs considered previously as essential in global transposon analyses: $m g 224$ and mg350.1 (Glass et al., 2006; Hutchison et al., 1999). The transposon insertion in clone 49 is located $41 \mathrm{bp}$ downstream of the start codon of $m g 350.1$, which encodes a hypothetical membrane protein. The transposon insertion in clone 39 is located 448 bp downstream of the start codon of the $m g 224$, which is currently annotated as the $f t s Z$ gene, involved in cell division. A comprehensive study of this mutant is in progress; preliminary data do not show an abnormal growth of this mutant in SP-4 medium.

A significant number of insertions (15 out of 49) that led to lacZ expression were found in intergenic regions, suggesting the absence of terminator sequences in many $M$. genitalium ORFs, in agreement with previous expectations derived from computer analyses which found few (Ermolaeva et al., 2000) or no (Washio et al., 1998) terminator sequences in the M. genitalium genome. Moreover, $50 \%$ of the insertions in intergenic regions were found in $\mathrm{MgPa}$ islands. The presence of transcripts derived from $\mathrm{MgPa}$ islands was further confirmed by specific RT-PCR amplifications from total RNA of the G-37 (wildtype) strain (Fig. 2b). This result was unexpected because these regions are relatively long and in some cases are far away from a putative ORF which could drive their transcription. For instance, the distance between the transposon insertion in MgPa II and tRNA-Thr, the closest annotated locus (apart from $m g 199$, which is annotated as a pseudogene and has not been taken into account here, see Supplementary Fig. S1), is $72 \mathrm{~kb}$. In addition, a terminator sequence that could block the upstream transcripts is predicted upstream of the transposon insertion in clone 41 (very close to $\mathrm{MgPa}$ VII, Fig. 2d). These results suggest the presence of promoter sequences either inside or in the vicinity of the $\mathrm{MgPa}$ islands.

\section{Monitoring gene expression level using the promoterless vector}

The background noise of $\beta$-Gal activity of the G-37 strain was found to be very low, $0.12 \pm 0.07$ Miller units per $0.1 \mathrm{nmol}$ ATP. The $\beta$-Gal activity values of the different clones with transposon insertions were in the range 8-2500 Miller units per $0.1 \mathrm{nmol}$ ATP. The reliability of the values obtained was assessed by triplicate measures of the $\beta$-Gal activity from two independent cultures of one of the clones (Table 3). Once corrected according to the culture biomass by measuring the ATP content, $\beta$-Gal activity values were very reproducible and found to be independent of the stage of the culture, at least in a range of $24 \mathrm{~h}$. This demonstrates that promoter fusions with lac $Z$ can be used in a reliable way to quantify the gene expression levels in M. genitalium cell cultures. 
The highly transcribed insertions were mainly located inside coding regions and in sense with the predicted ORFs. Five insertions were located in ORFs related to DNA metabolism, three in ORFs related to protein synthesis, three in ORFs related to membrane proteins, two in ORFs related to nucleotide synthesis and one in ORFs related to transport. In addition, six insertions were located inside ORFs of unknown function or coding for hypothetical proteins. The mg191 ORF (MgPB, P140 adhesin) was found to be the most highly transcribed gene, reinforcing its role as a major virulence factor in $M$. genitalium. Interestingly, P1 adhesin precursor homologues of P140 are also among the most highly transcribed ORFs in $M$. pneumoniae (Weiner et al., 2003).

There is evidence that highly expressed genes exhibit a bias towards a subset of synonymous codons, which are those most accurately and/or efficiently recognized by the most abundant tRNA species (Sharp et al., 2005). The possible existence of a codon usage bias in the ORFs described above was investigated by comparing the codon usage average in the ORFs of the M. genitalium complete genome with the codon usage average in this subset of highly expressed ORFs. Although most codons did not show any significant bias, the usage for the UAA stop codon was $72 \%$ in the whole genome whereas in highly transcribed ORFs it was $92 \%$, similar to that described for highly expressed genes of B. subtilis (Rocha et al., 1999). Slight differences were also found for the His CAC codon usage, which was $35 \%$ in the whole genome and $41 \%$ in highly transcribed transposon insertions. However, these differences are very small and support previous computer analyses indicating that highly expressed genes of several species, including M. genitalium, have no discernible differences in codon usage compared to other genes (Henry \& Sharp, 2007).

\section{Transposon insertion reveals antisense transcription}

Although transposon insertions were found mainly in sense with respect to the putative transcript derived from the interrupted ORF, there was also a considerable number of insertions (14 out of 34) where the lacZ gene was transcribed from the unexpected strand. In addition, transposon insertions in both orientations were identified in $m g 191$, $m g 269$ and $m g 298$ ORFs. The presence of these antisense transcripts was confirmed by RT-PCR from total RNA of the G-37 strain (Figs 2 and 3). This result is in agreement with a recent report by Benders et al. (2005) in which antisense transcription was also detected in the M. genitalium $\mathrm{fts} Z$ operon. It is noteworthy that many of these antisense transcripts give rise to high levels of $\beta$-Gal activity. For instance, the $\beta$-Gal activity from the mg269 antisense transcript (clone 21) is twofold higher than that from the sense transcript (clone 30 ) and the $\beta$-Gal activity from the $m g 191$ antisense transcript (clone 46) is only threefold lower than that from the sense transcript (clone 51), the most highly expressed lac $Z$ insertion found in our work.
Attempts to better characterize antisense transcripts by Northern blot analyses were unsuccessful and previous studies have reported difficulties in using this method for M. genitalium (Musatovova et al., 2003). In the absence of data corresponding to the size of the transcripts, the start points of some of them were determined by performing consecutive primer extension reactions with RNA from the G-37 strain until a transcriptional start point was found. This procedure was used to locate the transcriptional origin of the $m g 354$ antisense transcript and that corresponding to the transcript from the minus strand of the $\mathrm{MgPa} \mathrm{VI}$ island. One band of $134 \mathrm{nt}$ revealed the transcriptional start point of the $m g 354$ antisense transcript, which was located upstream of the mg355 ORF (Fig. 4a). The sequence 5'TATAAT $-3^{\prime}$ has been identified as the putative -10 box and is probably the promoter region of the mg355 ORF (Fig. 4a). The absence of a terminator sequence between $m g 354$ and $m g 355$ led us to think that the antisense transcript detected in the $m g 354$ ORF is derived from the promoter of the $m g 355 \mathrm{ORF}$. The absence of a transcription terminator sequence between the two ORFs was confirmed by RT-PCR (Fig. 3, mg354). On the other hand, two bands of 284 and $285 \mathrm{nt}$ revealed the heterogeneous transcriptional start point of the $\mathrm{MgPa} \mathrm{VI}$ island transcript, which was located $257 \mathrm{bp}$ upstream of the transposon insertion site in clone 19 (Fig. 4b). The presence of alternative transcriptional start points has been previously reported in several M. genitalium ORFs (Musatovova et al., 2003, 2006a; Pich et al., 2006b). The putative -10 box is $5^{\prime}$-TATACT- $3^{\prime}$ and shows similarity to the -10 boxes previously described for cytadherence-related operons of M. genitalium (Musatovova et al., 2003). Thus the $\mathrm{MgPa}$ island VI transcript is not the result of a run-on transcript including an additional ORF, but it seems to be derived from its own specific promoter located inside this region.

\section{DISCUSSION}

Given the limited understanding of many aspects of gene expression in mycoplasmas, the development of efficient tools for functional genomics in these bacteria is an outstanding challenge. In the present work, we have developed the pLacRBS ${ }^{+}$vector as a new transposon system to obtain gene promoter fusions with lac $Z$ in $M$. genitalium. The expression levels of the promoter fusions obtained can be easily measured and are highly reproducible. A first survey with pLacRBS $^{+}$has revealed the transcriptional status of many genes of $M$. genitalium and several unexpected features of the transcription in this micro-organism.

Since pLacRBS ${ }^{+}$is promoterless, the lac $Z$ gene is expected to be transcribed only in transposon insertions located in actively transcribed stretches of the M. genitalium genome. When the pLacRBS $^{+}$vector was used to transform $M$. genitalium cells, around $16 \%$ of blue colonies were obtained. This suggests that only a subset of transposon insertions is transcribed strongly enough to give rise to 
Table 2. Transposon insertion sites

\begin{tabular}{|c|c|c|c|c|c|c|}
\hline Clone & $\begin{array}{l}\text { Insertion } \\
\text { site }^{\star}\end{array}$ & $\beta-G a l \dagger$ & Locus $\ddagger$ & Gene/protein annotation $\S$ & $\begin{array}{c}\text { Closest annotated } \\
\text { locus } \|\end{array}$ & Gene/protein annotation $\S$ \\
\hline 6 & $28596(-)$ & 31 & MG024-MG025 & IG & MG029 (3107) & DJ-1/PfpI family protein (11) \\
\hline 38 & $39210(+)$ & 78 & MG033 (S) & $\operatorname{glpF}(14)$ & & \\
\hline 42 & $49678(-)$ & 41 & MG041-MG042 & IG & MG048 (8631) & $f f h(6)$ \\
\hline 11 & $70343(-)$ & 54 & MG061-MG475 & IG & MG475 (138) & $t R N A-S e r(13)$ \\
\hline 2 & $137862(+)$ & 175 & MG110 (S) & $\operatorname{rsg} A(13)$ & & \\
\hline 8 & $158144(-)$ & 1894 & MG131 (A) & HP (pseudogene) & MG132 (1525) & HIT domain protein (11) \\
\hline 4 & $167985(-)$ & 43 & MG139-MGrrnA16S & IG (MgPa island II) & MG479 (72301)] & \\
\hline 45 & $168266(-)$ & 38 & MG139-MGrrnA16S & IG (MgPa island II) & MG479 (72020) & \\
\hline 1 & $214663(-)$ & 102 & MG185-MG186 & IG (MgPa island IV) & MG479 (25623) & $t R N A-T h r(13)$ \\
\hline 33 & $214713(-)$ & 35 & MG185-MG186 & IG (MgPa island IV) & MG479 (25573) & \\
\hline 40 & $215408(-)$ & 27 & MG185-MG186 & IG (MgPa island IV) & MG479 (24878) & \\
\hline 13 & $215856(+)$ & 112 & MG185-MG186 & IG (MgPa island IV) & MG185 (3964) & Putative lipoprotein (7) \\
\hline 51 & $221997(+)$ & 2508 & MG191 (S) & $m g p A(7)$ & & \\
\hline 46 & $225310(-)$ & 887 & MG191 (A) & $m g p A(7)$ & MG479 (14976) & $t R N A-T h r$ \\
\hline 37 & $239068(-)$ & 8 & MG200 (A) & DnaJ domain protein $(6,2)$ & MG479 (1218) \} & IKINA-Inr (1つ) \\
\hline 39 & $269698(-)$ & 35 & MG224 (A) & $f t s Z(2)$ & MG240 (17134) & \\
\hline 7 & $271967(-)$ & 38 & MG226 (A) & APC permease (14) & MG240 (14865) & NAD adenylyl transferase (1) \\
\hline 23 & $274086(-)$ & 42 & MG227 (A) & thyA (5) & MG240 (12746) J & \\
\hline 27 & $274649(+)$ & 18 & MG227 (S) & thyA (5) & & \\
\hline 32 & $300802(-)$ & 1222 & MG251 (S) & $\operatorname{glyS}(13)$ & & \\
\hline 36 & $314112(+)$ & 165 & MG260-MG497 & IG $(\mathrm{MgPa}$ island $\mathrm{VI})$ & MG260 (3601) & Putative lipoprotein (7) \\
\hline 19 & $314179(-)$ & 28 & MG260-MG497 & IG $(\mathrm{MgPa}$ island $\mathrm{VI})$ & MG497 (1198) & $t R N A-\operatorname{Arg}(13)$ \\
\hline 30 & $326268(-)$ & 131 & $\operatorname{MG269}(S)$ & $\mathrm{CHP}$ & & \\
\hline 21 & $326871(+)$ & 227 & MG269 (A) & CHP & MG264 (5825) & Dephospho-CoA kinase (1) \\
\hline 3 & $327236(-)$ & 109 & MG269 -MG270 & IG & MG270(1207) & Lipoyltransferase (3) \\
\hline 47 & $342244(-)$ & 1802 & MG281 (S) & CHP & & \\
\hline 41 & $352665(+)$ & 51 & MG288 (A) & Pseudogene & MG504 (3463) & tRNA-Ser \\
\hline 24 & $353673(+)$ & 26 & MG288-MG289 & IG & MG504 (4471) & tRNA-Ser \\
\hline 25 & $362232(+)$ & 64 & MG294 (A) & MFS_1 transporter (14) & MG291 (6385) & Phosphonate $\mathrm{ABC}$ transporter \\
\hline 35 & $362815(+)$ & 68 & MG294-MG295 & IG & MG291 (6968) & $(14)$ \\
\hline 12 & $365837(-)$ & 46 & MG298 (S) & $\operatorname{smc}(10)$ & & \\
\hline 16 & $367230(+)$ & 397 & MG298 (A) & $\operatorname{smc}(10)$ & MG291 (11383) & $\begin{array}{l}\text { Phosphonate } \mathrm{ABC} \text { transporter } \\
\text { (14) }\end{array}$ \\
\hline 31 & $368623(-)$ & 20 & MG298-MG299 & IG & MG299 (1072) & $p t a(3)$ \\
\hline 17 & $394875(-)$ & 159 & MG316 (S) & ComEC/Rec2 related (11) & & \\
\hline 9 & $396161(-)$ & 103 & MG317 (S) & $h m w 3(7)$ & & \\
\hline 50 & $412680(-)$ & 1859 & MG328 (S) & $\mathrm{CHP}$ & & \\
\hline 49 & $449576(-)$ & 88 & MG350.1 (S) & Membrane protein (7) & & \\
\hline 29 & $451247(-)$ & 149 & $\overline{\text { MG354 (A) }}$ & CHP & MG355 (2510) & $c l p B(6)$ \\
\hline 10 & $456949(+)$ & 170 & MG358 (S) & $\operatorname{ruvA}(10)$ & & \\
\hline 26 & $458186(-)$ & 1445 & MG 359 (A) & $\operatorname{ruvB}(10)$ & MG360 (1309) & $\operatorname{ImpB} / \mathrm{MucB} / \mathrm{SamB}$ family (11) \\
\hline 5 & $460714(-)$ & 92 & MG522 (S) & $\operatorname{rps} T(13)$ & & \\
\hline 28 & $480518(+)$ & 46 & MG523-MG382 & IG & MG381 (948) & CHP \\
\hline 34 & $517314(+)$ & 59 & MG414 (A) & CHP & MG408 (6411) & $\operatorname{msr} A(6)$ \\
\hline 44 & $519683(+)$ & 67 & MG525 (A) & $\mathrm{CHP}$ & MG408 (8780) & msrA (0) \\
\hline 15 & $520395(-)$ & 104 & MG525 (S) & CHP & & \\
\hline 48 & $524140(-)$ & 91 & MG419 (S) & $\begin{array}{l}\text { DNA pol III, subunit } \gamma \\
\text { and } \tau(10)\end{array}$ & & \\
\hline 14 & $543334(+)$ & 52 & MG438 (S) & $h s d S(10)$ & & \\
\hline 22 & $543582(+)$ & 32 & MG438 (S) & $h s d S(10)$ & & \\
\hline 43 & $563309(-)$ & 25 & MG458 (S) & $h p t(5)$ & & \\
\hline
\end{tabular}

${ }^{*}(+)$ or $(-)$ indicates the DNA strand of the M. genitalium genome in which the coding strand $(+)$ of the lacZ gene of the transposon insertion is found.

$\dagger$ Miller units per $0.1 \mathrm{nmol}$ ATP.

$\ddagger$ Coding sequences disrupted by the transposon insertion are indicated in bold. Disrupted genes considered previously as essential in global 
Table 2. cont.

transposon analyses (Glass et al., 2006; Hutchison et al., 1999) are underlined. Non-disrupted genes are indicated in normal type. In parentheses it is indicated whether the transcript of the lacZ gene in the transposon insertion is in sense (S) or antisense (A) with respect to the putative transcript derived from the interrupted ORF. No sense indication is given when the transposon insertion is found in a non-coding region.

$\$ I G$, non-coding region; HP, hypothetical protein; CHP, conserved hypothetical protein. The main role(s) expected for the corresponding ORF is given as follows: (1) biosynthesis of cofactors; (2) cellular processes; (3) energy metabolism; (4) regulatory functions; (5) purines, pyrimidines, nucleotides and nucleosides; (6) protein fate; (7) cell envelope; (8) central intermediary metabolism; (9) transcription; (10) DNA metabolism; (11) unknown; (12) fatty acid and phospholipid metabolism; (13) protein synthesis; (14) transport and binding proteins; (15) structural RNA genes. IIThe closest annotated locus upstream to the lac $Z$ of the transposon insertion is indicated either when the transposon insertion is found in a noncoding region or when lac $Z$ is found in antisense inside a particular coding region. The distance (nt) from such a locus to the transposon insertion site is shown in parentheses. No locus is indicated when the transposon insertion is found in sense inside a particular coding region.

colonies exhibiting a detectable blue colour. The pLacRBS $^{+}$vector contains the RBS signal from the $B$. subtilis cit $Z$ gene. Although it could be argued that this sequence could act as a spurious promoter, the low percentage of blue colonies obtained, together with the fact that $\beta$-Gal activity values of the different clones are scattered in a range of two orders of magnitude (Table 2), strongly suggests that the $\beta$-Gal activity in promoter gene fusions is a measure of the gene expression level at the transposon insertion site. However, the RBS signal seems to be essential for the translation of the lac $Z$ gene because no blue colonies were observed after transformation with a version of the vector without the RBS signal (Halbedel \& Stulke, 2006). The presence of one stop codon in each one of the three possible reading frames in the inverted repeats of the minitransposon in pLacRBS ${ }^{+}$(Fig. 1b, c) interrupts the translation of any $M$. genitalium coding sequence at the insertion point, and therefore the lac $Z$ gene will be translated as an additional cistron in the transcripts containing it. This result demonstrates that an RBS box on mRNA efficiently promotes ribosome recruitment in $M$. genitalium, but does not exclude the possibility that other additional sequences, different from those complementary to the $3^{\prime}$ end of $16 \mathrm{~S}$ RNA, can also fulfil this function.

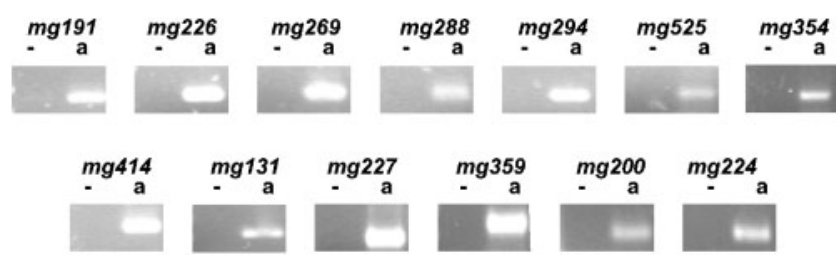

Fig. 3. Detection of antisense RNA transcripts from M. genitalium G-37. Transcripts from the minus strands of $m g 191, m g 226$, $m g 269, \mathrm{mg} 288, \mathrm{mg} 294, \mathrm{mg} 525, \mathrm{mg} 354, \mathrm{mg} 414, \mathrm{mg} 131$, $m g 227, m g 359, m g 200$ and $m g 224$ ORFs were detected by RT-PCR using primers described in Table 1 and are shown (right lanes) together with their respective negative controls (left lanes). The size of the bands is: $455 \mathrm{bp}$ ( $m g 191), 336 \mathrm{bp}$ ( $m g 226)$, 302 bp (mg269), 359 bp (mg288), 427 bp (mg294), 327 bp (mg525), 507 bp (mg354), 503 bp (mg414), 313 bp (mg131), $400 \mathrm{bp}$ (mg227), $432 \mathrm{bp}$ (mg359), $241 \mathrm{bp}(\mathrm{mg} 200)$ and $514 \mathrm{bp}$ (mg224).
The pLacRBS $^{-}$vector contains three stop codons located respectively at positions $-17,-25$ and -36 bp from the lac $Z$ start codon. As stated above, no blue colonies were obtained using this vector, suggesting that translational coupling can be expected in $M$. genitalium when a start codon is located less than 17 bp from the previous stop codon. This result is also relevant because the Rho factor has not been identified in Mycoplasma genomes and, in consequence, it is currently considered that polar effects derived from the appearance of a premature stop codon are only possible in genes exhibiting translational coupling (Waldo \& Krause, 2006). Thus, our results can be taken as a predictive tool to determine the chance that two cistrons may be translationally coupled.

No transposon insertions were found in several ORFs related to energy metabolism (i.e. pyruvate dehydrogenase and pyruvate kinase) or in the gene coding for the elongation factor Tu. Such ORFs were previously identified as highly transcribed in $M$. pneumoniae using microarrays (Weiner et al., 2003), but are not detected by our system, probably because they are essential and there is a reduced probability to recover transposon insertions inside these loci without disrupting gene expression.

Transposon insertions were found in the $m g 350.1$ and $m g 224$ ORFs described as essential in previous global transposon analysis (Glass et al., 2006; Hutchison et al., 1999). While mg350.1 is currently annotated as a putative membrane protein, the disruption found in $m g 224$ (annotated as fts $Z$ ) is somewhat puzzling. The $m g 224$ ORF codes for a highly conserved protein involved in cell

Table 3. $\beta$-Galactosidase activity from two independent cultures of clone 38

Clone 38 was selected among the first clones grown from blue colonies. The results are shown as Miller units per $0.1 \mathrm{nmol}$ ATP (mean \pm SE of three samples).

\begin{tabular}{|lccc|}
\hline Culture & $\mathbf{7 2} \mathbf{~ h}$ & $\mathbf{8 4} \mathbf{~ h}$ & $\mathbf{9 6} \mathbf{~ h}$ \\
\hline $38 \mathrm{~A}$ & $81.3 \pm 4.5$ & $77.2 \pm 6.2$ & $84.2 \pm 7.3$ \\
$38 \mathrm{~B}$ & $85.3 \pm 5.2$ & $82.7 \pm 5.7$ & $85.5 \pm 6.5$ \\
\hline
\end{tabular}



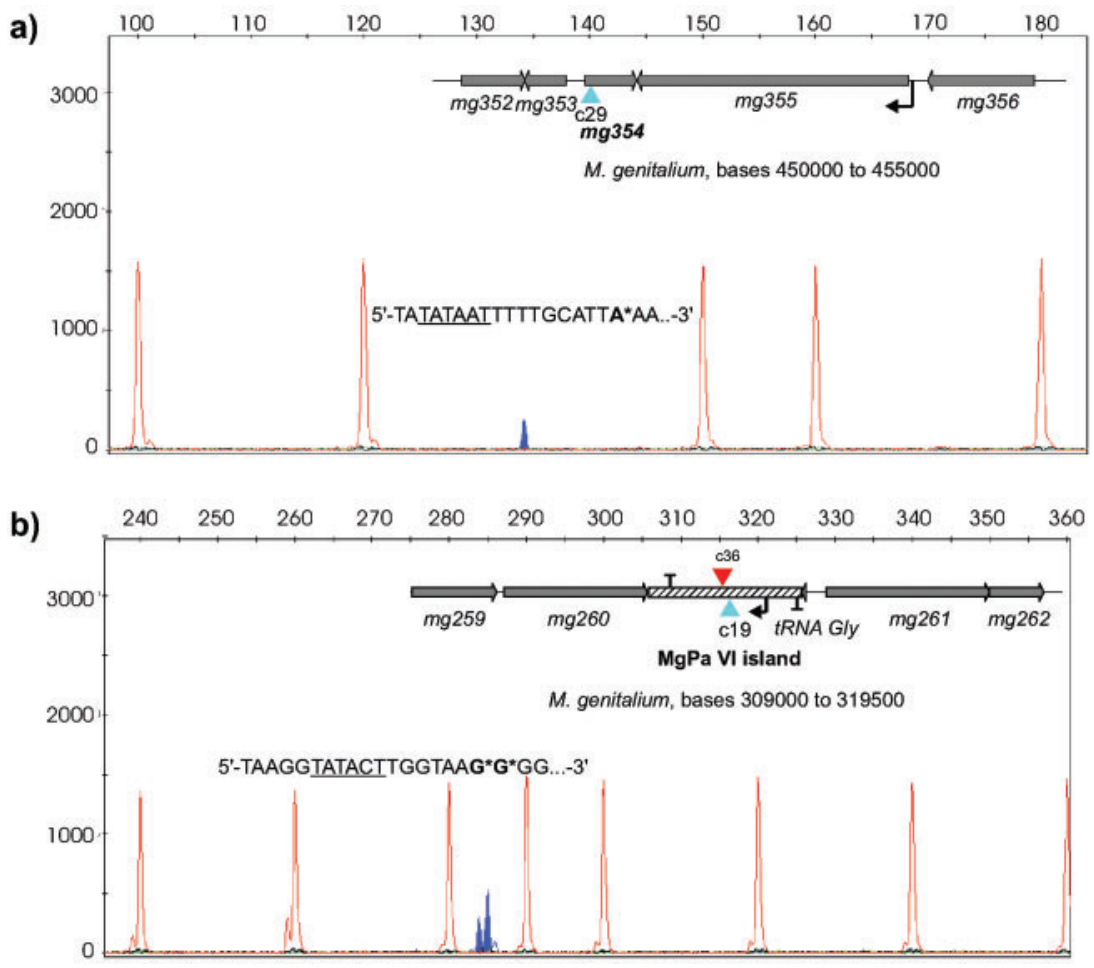

Fig. 4. Identification of the transcriptional start points of the antisense transcripts in $m g 354$ ORF (a) and the minus strand of the $\mathrm{MgPa}$ island $\mathrm{VI}(\mathrm{b})$. The oligonucleotides used in the primer extension reactions were mg354Fam and MgPaVIFam (Table 1). 5'-6-Fam-labelled cDNAs from primer extension reactions were analysed using an $\mathrm{ABI} 3130 \mathrm{XL}$ Genetic Analyzer and ROX markers. The ROX marker peaks are shown in red, while the sample is shown in blue. One peak of $134 \mathrm{nt}$ was detected by the GENESCAN program and corresponds to the transcriptional start point of the $\mathrm{mg} 355$ antisense transcript (in bold and labelled with * in the sequence). Two peaks of 284 and 285 nt were identified in the primer extension reactions of the transcripts from the minus strand of the $\mathrm{MgPa}$ island $\mathrm{VI}$ and correspond to the heterogeneous start point (in bold and labelled with * in the sequence). The putative -10 boxes are underlined in both sequences. division which is essential for cell viability in many microorganisms (Margolin, 2005). Also, it has been reported that truncated forms of FtsZ are not functional (Osawa \& Erickson, 2005). Although disruptions in other important genes like those coding for subunits of the DNA polymerase III or tRNA synthetases are not uncommon in global transposon analyses (Glass et al., 2006), the fts $Z$ gene is not found in the genomes of either Mycoplasma mobile (Jaffe et al., 2004) or the related mollicute Ureaplasma parvum (Glass et al., 2000). Our results also suggest that the fts $Z$ gene is not essential for cell division in M. genitalium and support the existence of alternative cell division mechanisms in Mollicutes. Further work characterizing the fts $Z$ mutant obtained may provide valuable information about mycoplasmal cell division mechanisms.

Several transposon insertions were found inside the $\mathrm{MgPa}$ islands, suggesting that they are actively transcribed from specific promoters located inside or in the vicinity of these regions. Because no start codons are present inside the coding sequences of the $\mathrm{MgPa}$ islands, it is thought that such sequences are untranslated unless they become transferred by recombination to the $\mathrm{MgPa}$ operon. In this sense, $\mathrm{MgPa}$ islands are currently considered as an antigenic variability reservoir (Iverson-Cabral et al., 2006; Musatovova et al., 2006b) and it is surprising to see that these untranslated regions are actively transcribed. In the same way, there is experimental evidence supporting the presence of a transcriptional terminator sequence in the $\mathrm{MgPa}$ island located downstream of the $f t s Z$ operon (Benders et al., 2005). Computer analyses also predict the presence of transcriptional terminator sequences in $\mathrm{MgPa}$
VI (Ermolaeva et al., 2000) (Supplementary Fig. S1), and such sequences also appear in most $\mathrm{MgPa}$ islands and in the $\mathrm{MgPa}$ operon. Moreover, we have identified a transcriptional start point for the minus strand of the $\mathrm{MgPa}$ island VI, suggesting the presence of a specific promoter sequence inside it. Since the sequences in the $\mathrm{MgPa}$ islands are reminiscent of similar sequences located in the $\mathrm{MgPa}$ operon, we propose that the transcriptional regulatory sequences found in the $\mathrm{MgPa}$ islands may be implicated in the regulation of the $\mathrm{MgPa}$ operon transcription. The presence in a blue colony of a transposon insertion with the lacZ gene in the opposite orientation to the mg191 ORF (clone 46; Table 2), supports the existence of an antisense transcript and suggests the presence of a promoter that could be involved in the regulation of the $\mathrm{MgPa}$ operon (Supplementary Fig. S2).

Thirty per cent of the recovered clones show transposon insertions in the opposite strand of the corresponding ORF, suggesting the presence of a large number of antisense transcripts along the $M$. genitalium genome. Although the presence of one antisense transcript has been recently reported in the fts $Z$ operon (Benders et al., 2005), our results provide experimental evidence for the generalized presence of antisense transcripts in M. genitalium. The presence of antisense transcripts could be related to the existence of unidentified reading frames in the opposite strand of currently annotated ORFs. However, we failed to detect stretches encoding peptides longer than 100 amino acids inside genes with transposon insertions in the minus strand. In addition, none of the potential peptides display similarity to any other known protein or peptide (data not 
shown). Besides that, the presence of antisense transcripts has been traditionally linked to the regulation of gene expression in archaea and eubacteria. This control is well documented and occurs at many levels, including premature transcription termination, facilitated mRNA decay, and direct or indirect inhibition of translation (Wagner \& Flardh, 2002). Despite most of the reported examples involving negative control, positive control is also possible (Morfeldt et al., 1995). In the absence of known regulatory proteins, antisense RNAs offer a promising and flexible mechanism to regulate gene expression in M. genitalium. In this way, the $\mathrm{MgPa}$ operon provides an interesting model to unravel the roles of the antisense RNAs in the control of the Mycoplasma gene expression.

\section{ACKNOWLEDGEMENTS}

This work was supported by grant BFU2004-06377-C02-01 from the Ministerio de Educación y Ciencia (MEC) to E. Q. and by the Centre de Referencia en Biotecnologia de la Generalitat de Catalunya. M. L.-S. acknowledges a FPI predoctoral fellowship from the MEC. Thanks are also given to Dr J. L. Arolas for fruitful discussions and to Anna Barceló (Servei de Seqüenciació UAB) for DNA sequencing.

\section{REFERENCES}

Altschul, S. F., Madden, T. L., Schaffer, A. A., Zhang, J., Zhang, Z., Miller, W. \& Lipman, D. J. (1997). Gapped BLAST and PSI-BLAST: a new generation of protein database search programs. Nucleic Acids Res 25, 3389-3402.

Benders, G. A., Powell, B. C. \& Hutchison, C. A., III (2005). Transcriptional analysis of the conserved $\mathrm{fts} Z$ gene cluster in Mycoplasma genitalium and Mycoplasma pneumoniae. J Bacteriol 187, 4542-4551.

Chiner, E., Signes-Costa, J., Andreu, A. L. \& Andreu, L. (2003). [Mycoplasma pneumoniae pneumonia: and uncommon cause of adult respiratory distress syndrome]. An Med Interna 20, 597-598 (in Spanish).

Dybvig, K., French, C. T. \& Voelker, L. L. (2000). Construction and use of derivatives of transposon Tn4001 that function in Mycoplasma pulmonis and Mycoplasma arthritidis. J Bacteriol 182, 4343-4347.

Ermolaeva, M. D., Khalak, H. G., White, O., Smith, H. O. \& Salzberg, S. L. (2000). Prediction of transcription terminators in bacterial genomes. J Mol Biol 301, 27-33.

Glass, J. I., Lefkowitz, E. J., Glass, J. S., Heiner, C. R., Chen, E. Y. \& Cassell, G. H. (2000). The complete sequence of the mucosal pathogen Ureaplasma urealyticum. Nature 407, 757-762.

Glass, J. I., Assad-Garcia, N., Alperovich, N., Yooseph, S., Lewis, M. R., Maruf, M., Hutchison, C. A., III, Smith, H. O. \& Venter, J. C. (2006). Essential genes of a minimal bacterium. Proc Natl Acad Sci U S A 103, 425-430.

Halbedel, S. \& Stulke, J. (2006). Probing in vivo promoter activities in Mycoplasma pneumoniae: a system for generation of single-copy reporter constructs. Appl Environ Microbiol 72, 1696-1699.

Henry, I. \& Sharp, P. M. (2007). Predicting gene expression level from codon usage bias. Mol Biol Evol 24, 10-12.

Hutchison, C. A., Peterson, S. N., Gill, S. R., Cline, R. T., White, O., Fraser, C. M., Smith, H. O. \& Venter, J. C. (1999). Global transposon mutagenesis and a minimal Mycoplasma genome. Science 286, 2165-2169.
Iverson-Cabral, S. L., Astete, S. G., Cohen, C. R., Rocha, E. P. \& Totten, P. A. (2006). Intrastrain heterogeneity of the $m g p B$ gene in Mycoplasma genitalium is extensive in vitro and in vivo and suggests that variation is generated via recombination with repetitive chromosomal sequences. Infect Immun 74, 3715-3726.

Jaffe, J. D., Stange-Thomann, N., Smith, C., DeCaprio, D., Fisher, S., Butler, J., Calvo, S., Elkins, T., FitzGerald, M. G. \& other authors (2004). The complete genome and proteome of Mycoplasma mobile. Genome Res 14, 1447-1461.

Jensen, J. S. (2004). Mycoplasma genitalium: the aetiological agent of urethritis and other sexually transmitted diseases. J Eur Acad Dermatol Venereol 18, 1-11.

Knudtson, K. L. \& Minion, F. C. (1993). Construction of Tn4001lac derivatives to be used as promoter probe vectors in mycoplasmas. Gene 137, 217-222.

Lloyd, A. L., Marshall, B. J. \& Mee, B. J. (2005). Identifying cloned Helicobacter pylori promoters by primer extension using a FAMlabelled primer and GENESCAN analysis. J Microbiol Methods 60, 291-298.

Madsen, M. L., Nettleton, D., Thacker, E. L., Edwards, R. \& Minion, F. C. (2006a). Transcriptional profiling of Mycoplasma hyopneumoniae during heat shock using microarrays. Infect Immun 74, 160-166.

Madsen, M. L., Nettleton, D., Thacker, E. L. \& Minion, F. C. (2006b). Transcriptional profiling of Mycoplasma hyopneumoniae during iron depletion using microarrays. Microbiology 152, 937-944.

Margolin, W. (2005). FtsZ and the division of prokaryotic cells and organelles. Nat Rev Mol Cell Biol 6, 862-871.

Mclnerney, J. O. (1998). GCUA: general codon usage analysis. Bioinformatics 14, 372-373.

Miller, F. D. \& Hershberger, C. L. (1984). A quantitative betagalactosidase alpha-complementation assay for fusion proteins containing human insulin B-chain peptides. Gene 29, 247-250.

Morfeldt, E., Taylor, D., von Gabain, A. \& Arvidson, S. (1995). Activation of alpha-toxin translation in Staphylococcus aureus by the trans-encoded antisense RNA, RNAIII. EMBO J 14, 4569-4577.

Musatovova, O., Dhandayuthapani, S. \& Baseman, J. B. (2003). Transcriptional starts for cytadherence-related operons of $\mathrm{Myco-}$ plasma genitalium. FEMS Microbiol Lett 229, 73-81.

Musatovova, O., Dhandayuthapani, S. \& Baseman, J. B. (2006a). Transcriptional heat shock response in the smallest known selfreplicating cell, Mycoplasma genitalium. J Bacteriol 188, 2845-2855.

Musatovova, O., Herrera, C. \& Baseman, J. B. (2006b). Proximal region of the gene encoding cytadherence-related protein permits molecular typing of Mycoplasma genitalium clinical strains by PCR-restriction fragment length polymorphism. J Clin Microbiol 44, 598-603.

Osada, Y., Saito, R. \& Tomita, M. (1999). Analysis of base-pairing potentials between $16 \mathrm{~S}$ rRNA and $5^{\prime}$ UTR for translation initiation in various prokaryotes. Bioinformatics 15, 578-581.

Osawa, M. \& Erickson, H. P. (2005). Probing the domain structure of FtsZ by random truncation and insertion of GFP. Microbiology 151, 4033-4043.

Peterson, S. N., Bailey, C. C., Jensen, J. S., Borre, M. B., King, E. S., Bott, K. F. \& Hutchison, C. A., III (1995). Characterization of repetitive DNA in the Mycoplasma genitalium genome: possible role in the generation of antigenic variation. Proc Natl Acad Sci U S A 92, 11829-11833.

Pich, O. Q., Burgos, R., Ferrer-Navarro, M., Querol, E. \& Pinol, J. (2006a). Mycoplasma genitalium mg200 and mg386 genes are involved in gliding motility but not in cytadherence. Mol Microbiol 60, 1509-1519. 
Pich, O. Q., Burgos, R., Planell, R., Querol, E. \& Pinol, J. (2006b). Comparative analysis of antibiotic resistance gene markers in Mycoplasma genitalium: application to studies of the minimal gene complement. Microbiology 152, 519-527.

Reddy, S. P., Rasmussen, W. G. \& Baseman, J. B. (1996). Isolation and characterization of transposon Tn4001-generated, cytadherence-deficient transformants of Mycoplasma pneumoniae and Mycoplasma genitalium. FEMS Immunol Med Microbiol 15, 199-211.

Robertson, J. A. R. \& Stemke, G. W. (1995). Measurement of mollicute growth by ATP-dependent luminometry. In Molecular and Diagnostic Procedures in Mycoplasmology, pp. 65-71. Edited by S. Razin \& J. G. Tully. San Diego, CA: Academic Press.

Rocha, E. P., Danchin, A. \& Viari, A. (1999). Translation in Bacillus subtilis: roles and trends of initiation and termination, insights from a genome analysis. Nucleic Acids Res 27, 3567-3576.

Shapira, S. K., Chou, J., Richaud, F. V. \& Casadaban, M. J. (1983). New versatile plasmid vectors for expression of hybrid proteins coded by a cloned gene fused to lac $Z$ gene sequences encoding an enzymatically active carboxy-terminal portion of beta-galactosidase. Gene 25, 71-82.
Sharp, P. M., Bailes, E., Grocock, R. J., Peden, J. F. \& Sockett, R. E. (2005). Variation in the strength of selected codon usage bias among bacteria. Nucleic Acids Res 33, 1141-1153.

Tully, J. G., Rose, D. L., Whitcomb, R. F. \& Wenzel, R. P. (1979). Enhanced isolation of Mycoplasma pneumoniae from throat washings with a newly-modified culture medium. J Infect Dis 139, 478-482.

Wagner, E. G. \& Flardh, K. (2002). Antisense RNAs everywhere? Trends Genet 18, 223-226.

Waldo, R. H., III \& Krause, D. C. (2006). Synthesis, stability, and function of cytadhesin P1 and accessory protein B/C complex of Mycoplasma pneumoniae. J Bacteriol 188, 569-575.

Washio, T., Sasayama, J. \& Tomita, M. (1998). Analysis of complete genomes suggests that many prokaryotes do not rely on hairpin formation in transcription termination. Nucleic Acids Res 26, 5456-5463.

Weiner, J., III, Herrmann, R. \& Browning, G. F. (2000). Transcription in Mycoplasma pneumoniae. Nucleic Acids Res 28, 4488-4496.

Weiner, J., III, Zimmerman, C. U., Gohlmann, H. W. \& Herrmann, R. (2003). Transcription profiles of the bacterium Mycoplasma pneumoniae grown at different temperatures. Nucleic Acids Res 31, 6306-6320.

Edited by: C. Citti 